\title{
Os primeiros passos do Protestantismo na Amazônia
}

\author{
Liliane Costa de Oliveira* \\ Marilina Conceição Oliveira Bessa Serra Pinto*
}

\section{Resumo}

Este artigo aborda o processo histórico de inserção do protestantismo na Amazônia, período marcado pela Cabanagem (1835-1840), pelo crescimento da economia gomífera (1879-1912), momento em que as cidades de Belém e Manaus se destacam no cenário internacional, o que ocasionou forte crescimento demográfico. Essa intensa movimentação populacional e a riqueza criada pela economia da borracha fizeram dessas cidades alvos também do protestantismo. Trata-se de uma discussão onde se descreverá os primeiros passos do protestantismo na Amazônia, destacando a atuação missionária como um importante instrumento para a consolidação desse movimento religioso na região, além de apontar a Igreja Metodista como a primeira igreja protestante a se instalar na região Norte no século XIX.

Palavras-chave: Amazônia. Protestantismo. Missionários. Metodismo.

\section{The first steps of protestantism in the Amazon Region}

\section{Abstract}

This article discusses the historical process Protestantism insertion in the Amazon region, a period marked by Cabanagem (1835-1840), the growth of the economy rubber gum (1879-1912), at the cities of Belem and Manaus that stand out in the international scenario, which led to a strong population growth. This intense population movement,

* Doutoranda do Programa de Pós-Graduação Sociedade e Cultura na Amazônia (UFAM), Mestra em Sociologia (UFAM), Bacharel em Ciências Teológicas (FBN); Licenciada em Ciências Sociais (UFAM). Professora do Departamento de Ciências Teológicas da Faculdade Boas Novas de Ciências Teológicas, Sociais e Biotecnológicas (FBN). E-mail: lilioliveira123@yahoo.com.br. Endereço para acessar Currículo Lattes: http://lattes.cnpq. br/4095269474694245

** Doutora em Ciências Sociais (PUC). Mestra em Filosofia do Conhecimento (UP-Universidade do Porto) Professora no Departamento de Filosofia e integra o corpo docente do Programa da Pós-Graduação em Sociologia, da Universidade Federal do Amazonas. E-mail: marilina-pinto@gmail.com.br. Endereço para acessar Currículo Lattes: http:// lattes.cnpq.br/8482510161447799 
along with the wealth created by the rubber economy made these cities targets also of Protestantism. This is a discussion where we describe the first steps of the Protestant Church in the Amazon, highlighting the missionary work as an important instrument for the consolidation of Protestantism in the region, while pointing out the Methodist Church as the first Protestant church to settle in the North in the nineteenth century.

Key-words: Amazon. Protestantism. Missionaries. Methodism.

\section{Los primeros pasos del protestantismo en la Región Amazónica}

\section{Resumen}

Este artículo aborda el proceso de inserción histórica del protestantismo en la región amazónica, un período marcado por Cabanagem (1835-1840), el crecimiento de la economía gomífera (1879 hasta 1912), en las ciudades de Belém y Manaus se destacan en el escenario internacional, lo que llevó a un fuerte crecimiento de la población. Este movimiento poblacional intenso, junto con la riqueza creada por la economía del caucho hizo estas metas ciudades también del protestantismo. Esta es una discusión en donde se describen los primeros pasos de la Iglesia Protestante en el Amazonas, destacando el trabajo misionero como un instrumento importante para la consolidación del protestantismo en la región, al tiempo que señala la Iglesia Metodista como la primera iglesia protestante a instalarse en el Norte en el siglo XIX.

Palabras clave: Amazonía. Protestantismo. Misioneros. Metodismo.

\section{Introdução}

Nos séculos XVI e XVII, além do domínio luso-espanhol, o Brasil foi invadido por mais duas nações europeias: a França e a Holanda. Muitos dos invasores eram protestantes, o que provocou forte reação dos portugueses, numa época em que estava em pleno curso a Contrarreforma. Após a expulsão dos holandeses, o Brasil fechou suas portas aos protestantes por mais de 150 anos. Foi somente no século XVIII, com a vinda da família real portuguesa, que essa situação começou a modificar-se. Em 1810, Portugal e Inglaterra firmaram um Tratado de Comércio e Navegação, concedendo tolerância religiosa aos imigrantes protestantes.

A partir desse período, o protestantismo criou raízes no Brasil, expandindose por todos os lugares do país, mesmo que lentamente. Na Amazônia, o processo histórico de inserção do protestantismo é marcado pela Cabanagem (1835-1840), pelo crescimento da economia gomífera (1879-1912), e pela abertura política da transição do Império para a República (VILHENA, 2008).

Os missionários protestantes são personagens pouco estudados em análises da história do Brasil, isto quer dizer que os mesmos são uma rica fonte também para entender os processos sócio-históricos que marcaram a 
Amazônia. Dessa forma, as primeiras tentativas da missão protestante na Amazônia tinham como objetivo a evangelização da população local. Desse modo, os objetivos de divulgação da mensagem protestante, de conversão, de proselitismo e de distribuição de Bíblias talvez não tenham sido atingidos da maneira como os missionários esperavam, nem com a rapidez que desejavam, todavia, tal movimento religioso permaneceu e se expandiu, configurando um novo campo religioso.

Portanto, este artigo descreve os primeiros passos do protestantismo na Amazônia, destacando a atuação missionária como um importante instrumento para a sua consolidação, além de apontar a Igreja Metodista como a primeira igreja protestante a se instalar na região no século XIX. Convém ressaltar que as citações de cartas, jornais e diários que serviram de referência ao longo do trabalho são de análise de alguns autores que fundamentaram os dados históricos para a construção deste artigo.

\section{As razões da vinda dos primeiros missionários protestantes para a Amazônia}

A partir dos registros históricos de Martin Dreher, a presença de protestantes na Amazônia dá-se a partir de 1824, antes desse período somente alguns representantes diplomáticos e alguns viajantes estiveram na região. Esse intelectual também destaca a imigração, nos anos de 1766-1768 (quando ainda estava em Belém, o inquisidor Giraldo José de Abranches), de cerca de 87 alemães, dos quais 85 eram homens. Eles vieram como parte da política pombalina no sentido de reorganizar o império português. Os homens, já casados com mulheres portuguesas, se fixaram na Vila Viçosa da Madre de Deus, no território do atual Estado do Amapá. Deles, não se tem hoje mais notícias, nem se de fato eram protestantes (CERETTA, 2008).

Os dados da historiografia regional mostram a presença de protestantes na Amazônia, os quais estiveram envolvidos ao longo de uma disputa política e econômica. São nações estrangeiras de origem protestante que tentaram fixar as suas bases nesse território (séculos XVI e XVII), como é o caso dos holandeses.

As bases coloniais da Amazônia Holandesa [...] têm início nas possessões antilhanas [...], passando pela [...] América do Sul (Costa Venezuelana e Guianense), chagando até o Amazonas [...]. No Xingu, os fortes Nassau e Orange (1559; na região de Tocujus, entre o Jari e o Amapá (1610); os fortes Mariocaí ou Gurupatuba (Gurupá, hoje) em 1913. [...]. As feitorias holandesas (nos atuais Estados do Pará e territorial federal do Amapá) tinham essas fortificações como apoio (SILVA, 1996, p. 17). 
O forte Orange, no Xingu, descrito pela autora Marilene Silva, não historiciza somente a presença de holandeses que disputavam um pedaço de terra no território amazônico, contudo, marca também a presença de protestantes na Amazônia. Trata-se de um forte que faz referência a Guilherme de Orange, grande defensor da plena liberdade religiosa no contexto da luta contra a tirania espanhola, luta essa liderada por Orange, que abraçou o calvinismo, em 1573, e conquistou a independência da Holanda em 26 de julho de 1581. Assim, sob o influxo da fé reformada e da recém-conquistada autonomia política, a Holanda tornou-se uma das nações mais prósperas da Europa, criando um império comercial que se estendeu por todos os continentes (MATOS, 2011).

Destarte, a Amazônia passa a ser alvo do movimento protestante com a vinda de missões norte-americanas para o Brasil no século XIX. Os autores Mendonça e Filho (2002) afirmam que os norte-americanos transferiram para a América Latina os benefícios do "sonho americano", cujos componentes são patriotismo, racismo e protestantismo. Esse movimento marca a influência mais recente que o país passa a viver. Trata-se de um protestantismo da conversão, da mudança de vida, do proselitismo, em outras palavras, é assumir "o estilo americano de vida" (ALENCAR, 2005).

As justificativas da presença missionária protestante na América Latina são: "a Igreja Católica não fora capaz de garantir educação e a moralidade do subcontinente; não dera Bíblias ao povo na própria língua; não formara um clero idôneo, intelectual ou eticamente; pregara um evangelho deformado e não tinha recursos para evangelizar toda a América Latina”. Note que o "sonho americano" também aponta para a cristianização do mundo por meio do protestantismo norte-americano. Isto quer dizer, que o "povo escolhido" por Deus para expandir o seu reino na terra é a nação norte-americana. A expansão de tal "reino dominante americano" foi a estratégia missionária de conversão, "que consistia no rompimento abrupto do indivíduo com o seu meio cultural através da adoção de novos padrões de conduta opostos àqueles em que havia sido criado" (MENDONÇA; FILHO, 2002, p. 31-32).

Desde 1860, as potências econômicas estavam de olho no que acontecia no Brasil. Essa é uma das teses que explicam a razão da Amazônia aparecer interessante ao olhar protestante, pois ao mesmo tempo em que a Europa Central investia no Sul do país, grupos norte-americanos e ingleses "arregimentam-se para a futura posse da Amazônia", pois havia um desejo de separação dessa região do restante do Brasil. As causas para isso seriam os 
descasos que a Corte Portuguesa tratava a Província de Belém, explorando-a para o benefício de si mesma e de uns poucos indivíduos privilegiados por meio da Companhia do Visconde de Mauá, que possuía o monopólio do comércio e da navegação do Amazonas (PANTOJA, 2012, p. 105-106; VIEIRA, 1980).

O norte é a principal sede do movimento republicano, e mais, insinua-se que no caso do Imperador morrer, haverá o desmembramento do império e a formação de uma República Setentrional. Quão importante é que nossa influência religiosa pudesse ter um ano ou dois para fazer-se sentida e conhecida, antes que o tempo das novas cristalizações cheguem. [...] (HOLDEN apud VIEIRA, 1980, p. 177).

Essa passagem foi registrada pelo missionário Holden em seu diário, em 1860, período que chegava ao Pará, visando a propaganda protestante. Tal passagem aponta o entusiasmo e a sua aspiração para que o protestantismo se tornasse conhecido pelos moradores locais, antes da Amazônia tornar-se independente do restante do Brasil, uma vez que o Grão-Pará era um território onde já havia mobilizações políticas que poderiam levá-lo a essa desvinculação.

Outra razão que trouxe os protestantes norte-americanos para a Amazônia, foi a possível abertura do rio Amazonas à navegação internacional. ${ }^{1}$ Os Estados Unidos possuíam importantes interesses econômicos quanto à abertura dos rios brasileiros, sobretudo os rios na Bacia do Prata e do Amazonas, à navegação e ao comércio internacional, além disso, desde esse tempo já se sabia que a integração da Amazônia ao mundo dependia muito da navegação pelo rio Amazonas (ROSI, 2011). Desse modo, o desejo de desbravar e conquistar economicamente essa região fez que muitos migrassem para essa localidade, que seduzia exploradores com promessas de riqueza e prosperidade (CARVALHO, 2015).

O missionário presbiteriano estadunidense James Cooley Fletcher (18231901), que residiu no Brasil de 1851 a 1854, ao retornar para os Estados Unidos escreveu a obra "O Brasil e os Brasileiros" (1'. edição 1857) com o missionário metodista Daniel Kidder, onde ambos destacaram questões como a relação entre o Brasil e os Estados Unidos, entre elas a abertura do rio Amazonas.

\footnotetext{
1 As negociações entre norte-americanos e brasileiros pela abertura do rio Amazonas tiveram início em abril de 1853, e a partir do Decreto Imperial de 7 de dezembro de 1866, o rio e seus principais afluentes foram franqueados à navegação de navios mercantes de todas as bandeiras (ROSI, 2011).
} 
Rosi (2011, p. 79) enfatiza que “já em 1853 Fletcher suscitara a questão da abertura do rio Amazonas e publicara artigos sobre o assunto nos jornais do Rio de Janeiro". Na seção seguinte desse artigo se verá que essa foi uma das razões da vinda do missionário Holden para Belém.

Portanto, percebe-se que por trás das razões da missão protestante empreendida por missionários norte-americanos na Amazônia, havia também razões comerciais. Nota-se certa aproximação entre evangelização e interesses financeiros, os quais estavam incorporados pela ideologia do destino manifesto e do novo colonialismo. O desejo dos norte-americanos em tornar o rio Amazonas livre para a navegação internacional reflete os interesses imperialistas, os quais consistiam em estender os domínios estadunidenses, por isso a ideia de um povo escolhido por Deus para espalhar a fé cristã ao mundo desprovido do protestantismo não está dissociada das ideias de progresso norte-americano.

\section{Os primeiros missionários protestantes na Amazônia}

O protestantismo que se consolida na Amazônia é de origem missionária e conversionista. Os primeiros missionários protestantes que fizeram parte do projeto de propaganda protestante na Amazônia prepararam as bases para o estabelecimento das primeiras igrejas evangélicas na região.

Maués (2000, p. 88-89) destaca quais foram os primeiros missionários protestantes que vieram para a Amazônia:

O primeiro deles foi Daniel Parish Kidder que veio em 1839 [...]. Depois dele esteve na Amazônia o capitão naval norte-americano Robert Nesbit, que veio em 1857 [...]. Após a morte de Nesbit, ao que tudo indica seu trabalho continuou sendo realizado pelo escocês James Henderson, que já morava em Belém [...]. A Nesbit seguiu-se o missionário Richard Holden, que chegou ao Pará em 1860.

Daniel Parish Kidder (1815-1891) nasceu em New York (EUA), estudou em diversos colégios, e por último, formou-se na Wesleyan University em 1836, sob os princípios do metodismo. Converteu-se quando adolescente e se uniu à Igreja Metodista a contragosto da família. Desde então, decidiu-se pelo pastorado e chegou até a sonhar em ir para a China como missionário. Não conseguindo realizar esse propósito, aceitou o convite que lhe endereçou o bispo Waugh para trabalhar no Brasil (SALVADOR, 1982).

Daniel Kidder, em 1837, com apenas 22 anos de idade, com sua esposa Cynthia Russel (1817-1840), o professor Murdy e a Srta. Maraella Russel, 
também professora e talvez irmã de Cynthia, pois ambas tinham o mesmo sobrenome (LONG, 1968), foram enviados pela Sociedade Bíblica Americanaorganização protestante que enviou missionários para atuarem junto aos brasileiros -, para o Rio de Janeiro. Kidder veio para a Amazônia, em 1839. Belém foi a cidade onde propagou a "fé protestante" a bordo de navios e em casas de pessoas conhecidas. Viajou também pelo interior da Amazônia, distribuindo Bíblias e literatura cristã (MAUÉS, 2000).

Em sua obra "Reminiscências de Viagens e permanência no Brasil" Daniel Kidder (1972, p. 168) registra o período conturbado da Cabanagem, pois ao chegar ao Pará percebeu "os efeitos da revolução de 1835”. "Quase todas as ruas tem casas pontilhadas de balas ou varadas por projetéis de canhão. [...]. O convento de Santo Antônio ficou de tal forma exposto pelo canhoneio que ainda hoje exibe muitos sinais de balas pelas paredes." Kidder observou os estragos causados pelos bombardeios e tiroteios constantes entre cabanos e soldados da tropa imperial. Esse é o contexto sociopolítico da missão de Kidder na Amazônia.

Assim, os primeiros passos do protestantismo na Amazônia são marcados por um cenário intenso de mobilização popular, que perdurou praticamente por toda a década de 1830. Os cabanos, considerados como grupo social inferior, por viverem em casas simples às margens dos rios, rebelaram-se contra o poder político e econômico imposto na província paraense. Esse movimento político provocou o desligamento do Grão-Pará do restante do império.

Foram os próprios cabanos que proclamaram o Pará uma República. Essa movimentação política está registrada nos prédios da cidade de Belém, cenário que causa certo impacto ao missionário, o qual não explica os motivos que levaram os cabanos a se mobilizarem contra os ditames do governo lusitano nem tampouco explica a dimensão que esse movimento político-social tomou no Brasil e no mundo, mas se refere a esse momento de "desordens de 1835".

Segundo Vieira (1980), o trabalho missionário de Kidder no Pará foi a primeira tentativa de propaganda protestante no Norte do Brasil. Nessa época, o bispo de Belém, Dom Romualdo, foi avisado pelo bispo do Maranhão, Dom Marcos Antônio, de que Kidder estava a caminho de Belém. Informado de tal fato, o bispo do Pará escreveu ao presidente da Província, Dr. Bernardo de Souza, dizendo que Kidder era uma pessoa perigosa, por isso não se devia permitir a sua entrada em Belém. Kidder, ao chegar na Província, fez uma visita ao presidente para quem trouxera uma carta de 
apresentação, e após ter esclarecido quem era e o que estava fazendo deu início ao seu projeto missionário.

Kidder pertencia à Igreja Metodista Episcopal, ${ }^{2}$ sua estada no Brasil foi marcada por essa viagem de propaganda evangélica pela Amazônia, notabilizando-se assim como uma figura importante dos primórdios do protestantismo brasileiro. Além da região amazônica, viajou por todo o país, onde vendeu Bíblias e manteve contatos com intelectuais e políticos, como o padre Diogo Antônio Feijó, regente do Império.

Kidder, ao retornar de sua viagem do norte do Brasil, muito entusiasmado e satisfeito com o trabalho que realizou, encontrou sua mulher muito doente. Cynthia piorava a cada dia, vindo a morrer aos 22 anos de idade, de febre amarela, no dia 16 de abril de 1840 . Pouco se sabe a respeito de Cynthia Kidder, todavia, conforme a carta de Daniel Kidder aos pais de Cynthia, que comunica a sua morte, o mesmo mostra que sua mulher era uma cristã fervorosa, que havia se especializado para o trabalho missionário, dedicando-se a essa atividade de forma intensa. Aprendeu a língua portuguesa e era bastante conhecida e respeitada pela sua comunidade (LONG, 1968).

Em 1840, com a morte de sua mulher, no Rio de Janeiro, sem poder continuar suas atividades missionárias, devido à sua preocupação com os dois filhos, do choque sofrido pela perda da mulher, e a falta de recursos para dar continuidade às atividades missionárias, Kidder regressou aos Estados Unidos, aos 25 anos de idade (LONG, 1968).

A segunda tentativa de propagação da fé protestante na região Norte foi realizada pelo capitão naval e norte-americano Robert Nesbit (?-1858). ${ }^{3}$ Esse capitão marítimo veio ao Brasil com a missão de entregar navios ao governo peruano. Trouxe um carregamento de Bíblias e Novos Testamentos, e ao passar pela Amazônia aproveitou para distribuir e vender esses exemplares à população local. "A população ribeirinha impressionada com a visita dos grandes vapores que jogavam para o ar fogo e fumaça, comprava os livros do Capitão Nesbit, em grande espanto e admiração" (VIEIRA, 1980, p. 178).

Essa leitura de que os moradores locais adquiriam a Bíblia Sagrada com "grande espanto e admiração" denota que esse elemento era algo novo que chegava, desconhecido até então da população que vivia às margens dos rios

2 Foi a primeira igreja protestante a iniciar atividades missionárias junto aos brasileiros (183541). Seus principais líderes foram: Fountain Pitts, Justin Spaulding e Daniel Parish Kidder.

3 Devido às poucas informações sobre esse capitão, Vieira (1980, p. 178) aponta que a data de seu nascimento é desconhecida. 
amazônicos. No primeiro culto realizado por Marcus Carver - missionário que falaremos na última seção deste artigo -, em Manaus/Amazonas, ele perguntou aos dois homens que compareceram à reunião: "Vocês gostam da Bíblia?" A resposta foi: "Que espécie de animal é? Ele anda ou voa?" (CARVER apud CARVALHO, 2015).

Tal resposta demonstra total desconhecimento da Bíblia Sagrada. A Bíblia como o "novo" causava admiração não porque eram os textos sagrados do cristianismo, pois nem todos os que adquiriam a Bíblia sabiam de sua existência ou tinham acesso ao seu conteúdo por serem pouco alfabetizados nesse período. Mendonça, em sua obra, "O Celeste Porvir" (2008), enfatiza que o protestantismo, sendo a "religião do livro" no Brasil, enfrentou severo embaraço, a saber, o analfabetismo, principalmente no âmbito da população pobre que residia em áreas rurais.

Ao realizar tal atividade, Nesbit foi nomeado como agente da Sociedade Bíblica Americana no rio Amazonas, em julho de 1857. Mudou-se para Belém, porém, após um ano de atividade missionária, morreu na região, vitimado pela febre amarela, em 1858. Tudo indica que, após a morte de Nesbit, seu trabalho passou a ser realizado por James Henderson, comerciante escocês e protestante que morava em Belém. Esse comerciante também vendia Bíblias e distribuía literatura cristã em Belém. Antes da chegada de Richard Holden, Henderson possuía um estoque de literatura, o qual mais tarde cedeu ao mais novo missionário que chegara à Província (MAUÉS, 2000; VIEIRA, 1980).

Vieira (1980) aponta que a terceira tentativa de propaganda da fé protestante na Amazônia se dá com a chegada de Richard Holden à cidade de Belém. Todavia, Henderson foi importante para o sucesso das atividades de missão de Holden. James Henderson residia no Pará, desde 1832. Por viver nessa localidade por muito tempo e por estar muito bem estabelecido, em 1839, quando Daniel Kidder esteve em Belém, Henderson o hospedou em sua casa como forma de mostrar o seu apoio à missão de Kidder. Depois de 21 anos da visita de Kidder, acolheu Richard Holden. Henderson demonstrou ser amigo sincero de Holden, cooperando com ele tanto na distribuição de Bíblias quanto escrevendo artigos a favor do protestantismo.

O Conselho de Missões da Igreja Episcopal dos Estados Unidos e a Sociedade Bíblica Americana enviaram o missionário Richard Holden (1828-1886), em 1860, estabelecendo a presença da igreja protestante na Amazônia por meio da fundação de uma pequena capela em Belém do Pará (MAUÉS, 2000). 
Holden nasceu na Escócia, filho de um casal anglicano. Converteu-se aos 21 anos de idade. Esteve no Brasil em 1851, como comerciante, quando começou a estudar o português. Estudou Teologia no Seminário da Diocese de Ohio, nos EUA. Durante sua preparação para vir ao Brasil, além de estudar a língua portuguesa, traduziu o Livro de Oração Comum e artigos religiosos escritos nos tempos de seminarista.

Duas razões levaram Holden a escolher Belém do Pará para propagar o protestantismo. A primeira era que havia um posto de distribuição de Bíblias na cidade, fundado por Robert Nesbit, e possivelmente esse local estava sendo administrado por James Henderson. Era um importante ponto de contato para iniciar seu trabalho. A segunda era que havia uma expectativa de que o rio Amazonas seria aberto à navegação internacional. E ao estabelecer-se na cidade, passou a usar a imprensa local para difundir o evangelho, mas acabou por envolver-se em polêmica com o bispo de Belém, Dom Antônio de Macedo.

Holden, quando foi convidado para vir ao Brasil, foi aconselhado pelas duas organizações missionárias que trabalhasse "quietamente", ou seja, que não se envolvesse na política local e evitasse polêmicas, ordem que não foi cumprida, devido à intensa hostilidade ao propagar o evangelho, em virtude da oposição dos padres locais, bem como, a devoção acentuada aos santos católicos pela população local. Mesmo assim, tentou criar uma comunidade permanente, mas não teve sucesso, por ter sido praticamente expulso pelo bispo do Pará (VIEIRA, 1980).

Além de receber o apoio de James Henderson, na Província, outro amigo e protetor de Holden foi o cônsul suíço e protestante Louis Berlaz. O cônsul e a esposa tornaram-se amigos íntimos desse missionário. Entre os políticos paraenses, Tito Franco foi o maior colaborador que Holden teve, o qual o orientou em assuntos legais por ser também advogado e por permitir a publicação de seus artigos em seu jornal, o Jornal do Amazonas (VIEIRA, 1980).

Pela sua formação puritana, Holden tinha uma preocupação com a conversão pessoal, nesse sentido desenvolveu intensa atividade de proclamação do evangelho, incluindo as áreas ribeirinhas de difícil acesso. Viajou pela bacia do Amazonas, vendendo e distribuindo Bíblias e literatura cristã. Em 1862, mudou-se para Salvador, Bahia, onde sofreu perseguições pelo clero romano, e não teve êxito na evangelização. Em 1864, entrou em conflito com o Departamento de Missão da Igreja Episcopal Americana, que o subsidiava, e se desligou dele. O espírito polemista de Holden, seu confronto com as autoridades católicas romanas, e uma "dose" de preconceito contra o povo 
brasileiro, foram os prováveis motivos do insucesso de sua atividade na região (BARROS, 2010).

Fica evidente a visão de superioridade de Holden quanto aos costumes locais. Trata-se de um olhar etnocêntrico, pois via o povo, alvo de sua evangelização no Brasil, a partir do seu modo de ser, por isso ele queria, por meio do protestantismo, desenvolver a região, lugar onde viviam pessoas com costumes e valores religiosos diferentes.

O maior objetivo dos missionários protestantes, tanto na Amazônia como em todo o Brasil e outros países, alvos de sua evangelização, era promover a circulação de Bíblias vinculadas ao protestantismo e com suas traduções, garantindo sua gratuidade para os mais pobres e um preço acessível para quem pudesse pagar. Essa foi uma forma de propagar os ideais cristãos protestantes. Mendonça e Filho (2002) enfatizam que as denominações protestantes sempre entenderam que a leitura da Bíblia conduzia ao desenvolvimento pessoal e social, por isso investiram muitos recursos na impressão e distribuição de Bíblias.

Prova disso é a Sociedade Bíblica Americana, que surgiu no início do século XIX, e enviou Daniel Kidder ao Brasil. Essa organização objetivava a venda e a distribuição de Bíblias e literatura protestante ${ }^{4}$ em nações não protestantes e no idioma dos países visitados por seus membros, trabalho chamado de "colportagem" (FILHO, 2013).

Não nos descuramos de nossa missão de divulgar a Bíblia e folhetos evangélicos durante a nossa permanência na Província. Aproveitamos todas as oportunidades que se nos apresentaram de fazer o bem e conseguimos organizar a venda das Escrituras e a distribuição gratuita dos folhetos, de maneira que até hoje ainda perdura (KIDDER, 1972, p. 202).

Kidder ainda ressalta que os numerosos exemplares de Bíblias e folhetos evangélicos distribuídos ao público leitor do Pará exerceram "salutar influência no sentido de promover a tranquilidade geral e a prática da virtude" (1972, p. 202). Essa impressão de Kidder quanto ao acesso dos paraenses aos materiais de propaganda protestante deixa claro que ele se

\footnotetext{
4 São fascículos destinados à conversão dos não crentes, também chamados de folhetos evangélicos. Trata-se de uma compilação de pequenos resumos sobre temas variados como histórias bíblicas, aspectos da vida cristã, família, entre outros temas, são palavras de alerta que sejam oportunas aos "descrentes".

5 É a distribuição de publicações, livros e panfletos religiosos por pessoas chamadas "colportores".
} 
preocupava com a forma como esse grupo social se comportava, uma vez que a virtude para os protestantes pressupõe comportamentos éticos e rígidos, daí dos comportamentos dos grupos humanos da sociedade amazônica causar preocupação e espanto.

Mendonça (2008) afirma que o protestantismo constituiu-se como um modo de vida, e aceitá-lo implicava mudança nos padrões comportamentais e culturais. Sabe-se que o modo de vida, o modo de ser e o modo de crer dos grupos sociais que vivem na Amazônia possuem uma relação direta com a natureza. A respeito desse prisma, afirma-se que tornar-se protestante era negar tudo isso. Contudo, é relevante frisar que os comportamentos coletivos, as representações sociais, o conhecimento empírico acumulado, o sistema tradicional de crenças, símbolos e mitos é a marca dos grupos humanos da Amazônia, e romper com isso é "acabar" com um sistema construído ao longo de sua trajetória histórica.

Quanto à distribuição de Bíblias feita pelo missionário Holden, tal atividade foi criticada pelo bispo do Pará, D. Macedo Costa, em sua primeira Carta Pastoral, publicada assim que assumiu o bispado de Belém. Na Carta, afirmou que a base da fé católica não era a Bíblia, como era o caso "com a Babel do Protestantismo", mas era uma "autoridade viva, que falava e ensinava, uma Igreja visível e sempre presente” (VIEIRA, 1980, p. 182).

Em resposta, conforme o estudioso Vieira, Holden publicou, no Jornal do Amazonas - fundado em 1860, pelo conselheiro Tito Franco de Almeida, conhecido líder do partido liberal -, na edição de 17 de agosto de 1861, o seguinte anúncio:

Está à venda à Rua da Praia, no 43 a Bíblia Sagrada, de acordo com a tradução de João d’Almeida Pereira, por Rs. 1\$600. Também à venda a Bíblia Sagrada de acordo com a tradução do Padre Antônio Pereira de Figueiredo, por Rs. $1 \$ 800$, e Richard Holden convida todos a compararem-na com a tradução publicada em Lisboa, prometendo pagar Rs. $5 \$ 000$ por cada falsificação que possa ser encontrada (VIEIRA, 1980, p. 183).

Note que Holden resolveu desafiar o bispo supracitado a provar as falsificações alegadas nas chamadas "Bíblias Protestantes" (certamente devido à conhecida diferença entre as Bíblias católica e protestante). No dia 30 de agosto de 1861, em sua segunda Carta Pastoral, D. Macedo, depois de debater por 12 páginas sobre o que considerava serem as falsificações da "Bíblia protestante", proibiu os católicos de comprar e de possuir em suas casas a 
versão bíblica protestante, ordenando que deveria ser destruída ou guardada em um lugar onde não pudesse "fazer mal aos seus queridos" (VIEIRA, 1980, p. 182-183).

A venda ou distribuição de Bíblias Sagradas e folhetos evangélicos foi uma das principais estratégias dos missionários protestantes de levar o "reino" de Deus tanto na Amazônia quanto em outros lugares do Brasil. A venda ou distribuição de Bíblias se dava por ser um dos elementos que marcaram a protagonizada Reforma de Lutero, levando a população de sua época a ter acesso ao conhecimento bíblico.

Vale ressaltar que a missão empreendida pelos primeiros missionários protestantes - propagadores do evangelho e distribuidores de Bíblias que passaram pela região norte do Brasil, não foi totalmente um trabalho independente ou solitário, eles tiveram apoio de estrangeiros que residiam em Belém (norte-americanos, escoceses, entre outros), e de alguns paraenses. No caso de alguns missionários, como Daniel Kidder, os registros mostram que ele veio para o Brasil com sua mulher e filhos, isto quer dizer que os missionários também contavam com o apoio de suas famílias, além de receberem o apoio das organizações missionárias estrangeiras que os enviaram para o Brasil.

\section{O casal missionário Nelson e o estabelecimento da primeira Igreja Protestante na Amazônia}

Sendo a missão metodista a primeira a propagar o protestantismo na Amazônia, logo tal atividade culminou na fundação da primeira igreja protestante na região norte do Brasil, por intermédio do casal missionário Nelson. A presença dessa igreja com matriz na Reforma é a grande novidade do final do século XIX para a região amazônica.

É um protestantismo desvestido de símbolos mágicos, numa região onde a natureza é exuberante, habitada por indígenas, ribeirinhos, mestiços e quilombolas. Para esses grupos humanos, a natureza é o veículo da força divina, transmissora e comunicadora do poder de Deus.

Todavia, a visão de mundo do casal Nelson e dos demais missionários norte-americanos que vieram para o Brasil estava fundamentada pela ideologia do "destino manifesto", onde os Estados Unidos surgem como paradigma de uma sociedade perfeita, escolhida por Deus, com a importante missão de levar ao mundo o seu modo de vida (VILHENA, 2008). Os metodistas julgavamse ser o povo escolhido por Deus para estabelecer o cristianismo protestante no mundo todo. Foi essa a visão motivadora dos metodistas em alcançar os 
povos onde o protestantismo ainda não estava consolidado, com isso muitos missionários empenharam-se para expandi-lo.

Assim, o protestantismo na Amazônia recebe uma nova roupagem, onde a linguagem acerca de Deus trazida pelos protestantes passa a ser interpretada nos acontecimentos meteorológicos, nos cantos dos pássaros, na subida e descida dos rios e na ênfase ao local de culto. Segundo Ribeiro (2009), apesar de o protestantismo não apresentar forte destaque ao local de culto, o templo adquire a função de símbolo da presença divina e espaço sagrado.

No século XIX, época em que Belém e Manaus eram cidades que se destacavam no cenário internacional, devido à economia gomífera, isso ocasionou forte fluxo migratório e crescimento demográfico exorbitante para esse período. Essa intensa movimentação populacional, somada à riqueza criada pela economia da borracha, fez da cidade de Belém alvo também da igreja protestante (VILHENA, 2008).

As atividades missionárias do Reverendo Justus Henry Nelson realizaramse nesse contexto. Em 16 de julho de 1880, o pastor metodista William Taylor ${ }^{6}$ - o gigante das botas de sete léguas - veio à América do Sul pela segunda vez. O Pará foi o local escolhido inicialmente, e em sua companhia trouxe Walter Gregg, Justus Nelson e sua mulher Fannie. ${ }^{7}$ O reverendo Taylor ficou em Belém, após a chegada dele e do casal Nelson em Belém, durante duas semanas. Nesse interim, alugaram um edifício por $\$ 50$ dólares ao mês, dando início aos cultos em língua inglesa para alguns negociantes residentes na cidade, e onde também abriram uma escola de ensino para as crianças brasileiras, tendo a Bíblia como livro de leitura.

O casal missionário Nelson estabeleceu-se em Belém, oito anos antes da Proclamação da República, e ainda na vigência do regime do padroado ${ }^{8}$

6 Natural de Virgínia (EUA) e descendia de imigrantes escoceses-irlandeses. Converteu-se ao protestantismo em 1841, aos 20 anos de idade. Anos depois de sua conversão envolveu-se com a evangelização em diversas regiões de sua pátria, e também no Canadá, Inglaterra, Sul da África, Antilhas, Austrália, Índia, Angola, Moçambique, América do Sul, Costas do Pacífico e do Atlântico. O nome "O gigante das botas de sete léguas", foi atribuído a Taylor por ter levado a fé protestante em muitos lugares do mundo (SALVADOR, 1982).

7 Nelson nasceu, em 1851, no nordeste dos Estados Unidos. Formou-se em 1879, na Faculdade de Teologia da Universidade de Boston. Antes de vir para o Brasil, estudou enfermagem durante um ano. Enquanto Justus estava estudando em Boston, ele conheceu Fannie Bishop Capen, que havia nascido em Stoughton, Massachusetts, em 1852. Eles se casaram em 13 de abril de 1880, em Stoughton, Massachusetts.

8 Pelo padroado, a igreja de Roma concedia a um governante civil certo grau de controle sobre uma igreja nacional em apreciação por seu zelo cristão e como incentivo para futuras ações em favor da igreja (MATOS, 2011). 
(MAUÉS, 2000), onde residiram cerca de 45 anos, realizando um trabalho de alcance evangelístico e social, não só em Belém como em outras províncias da Amazônia Central. O trabalho do casal perdurou até 8 de novembro de 1925, e embora sob a direção de uma conferência anual dos Estados Unidos - Igreja Metodista Episcopal, o ramo do norte -, era custeado quase que exclusivamente pelo próprio casal Nelson.

William Taylor com Walter Gregg e o casal missionário Nelson estavam decididos a implantar o protestantismo na região, pois consideravam que a Amazônia era um lugar ainda desprovido da propaganda protestante (SALVADOR, 1980). Note que a propaganda protestante na Amazônia, a partir da cidade de Belém, traz consigo a antiga ideia de que essa região era desprovida de pessoas, de recursos econômicos, de cultura e sob a perspectiva religiosa protestante também carente da "fé cristã verdadeira". Desse modo, esse protestantismo que se estabelece nessa região ressignificou a prática religiosa, que para tal movimento religioso perpassa pela conversão, o que significa mudança de vida, assim o mundo para os moradores locais passou a ser ressignificado.

As atividades missionárias realizadas pelo casal Nelson na Amazônia faziam parte do sistema "missões de sustento próprio", projeto idealizado pelo Rev. Taylor, que recrutava jovens norte-americanos dispostos a propagar o protestantismo em lugares diversos. Reily (1982) destaca que Nelson foi um dos jovens recrutados por Taylor, quando ainda era estudante na Universidade de Boston, em 1878, época em que Taylor procurava, entre os estudantes, voluntários para servir como diretores e professores de colégios que ele tencionava estabelecer nas costas ocidental e oriental da América do Sul.

"Ele mesmo providenciava os obreiros e lhes custeava a viagem, desde que, um grupo de pessoas ali se dispusesse a apoiá-los, ajudando-os a se manterem" (SALVADOR, 1982, p. 54). Taylor preocupou-se em levar o metodismo aos lugares, considerados por ele, desprovidos do Evangelho e onde as pessoas necessitavam de "assistência espiritual", daí a idealização desse projeto que lhe permitiu evangelizar pessoas em tantos e tão variados lugares do mundo.

O meu sustento próprio foi sempre voluntário. Nunca pedi um vintém à Sociedade Missionária, porém, em diversas ocasiões durante estes 45 anos, tendo recebido dessa Sociedade mais de 2500 dólares como sinal do reconhecimento fraterno e oficial, a título de ajuda de custo (REILY, 1985, p. 9). 
A ajuda financeira que o casal Nelson recebia não era o suficiente para manter suas despesas pessoais e as de evangelização. Todavia, ao optarem pela "missão de sustento próprio", mantiveram-se com os recursos das aulas de matemática e línguas estrangeiras, inglês e alemão, o que possibilitou maior autonomia de ação no campo missionário e ampliou a sua participação e articulação em outras esferas da sociedade local (VILHENA, 2008).

Em 1881, o casal missionário passou a realizar o culto protestante na língua portuguesa, além disso, o setor escolar cresceu, de modo que a senhorita Hattie Curtiss veio juntar-se ao grupo, mas tanto ela como Walter Gregg retornaram aos Estados Unidos. Daí as razões por que, em junho de 1888, Taylor enviou novo reforço, constituído de John Nelson, irmão do Reverendo Justus Nelson, e duas professoras (SALVADOR, 1982), que morreram de febre amarela.

Por meio do crescimento do número de membros e do trabalho missionário metodista foi possível fundar, no dia 15 de julho de 1883, a Igreja Metodista Episcopal em Belém, no Estado do Pará. As atividades da igreja consistiam em cultos domésticos, Escola Bíblica Dominical, reunião de oração em casas particulares e instrução escolar às crianças.

Conforme descreve Salvador (1982, p. 56), nos dez anos que se seguiram, após a fundação dessa igreja, 51 pessoas fizeram a profissão de fé, sendo registrados no rol de membros 108 indivíduos. "A igreja cresceu, passando a contar, em 1895, com 44 membros professos, 26 candidatos e 250 simpatizantes, uma Liga Epworth (Sociedade Metodista de Jovens, organizada para a sua instrução na Bíblia e no trabalho missionário da igreja) e uma Sociedade Feminina de Temperança."

Veja que a teologia protestante, por meio dos metodistas, num primeiro momento, fixou-se no norte brasileiro de forma bastante lenta. Todavia, trouxe novos elementos religiosos ao mundo espiritual dos moradores locais, como a Bíblia Sagrada. Para os protestantes, ela é central em suas vidas, ela é a regra de fé e prática, é o meio para se conhecer a Deus e sua oferta de salvação em Jesus Cristo. Portanto, ela foi também instrumento para embasar e criar as representações da vida protestante no âmbito da cultura amazônica (CARVALHO, 2015).

As atividades missionárias do casal Nelson não se limitaram somente ao ensinamento da doutrina metodista ou à conversão dos moradores de Belém, mas eles se correspondiam também com pessoas do interior do Amazonas, instruindo-as no evangelho e na solução de problemas. Dedicaram-se ao 
trabalho social, atendendo aos doentes, até onde permitia o conhecimento de Nelson a respeito de enfermagem. Nelson traduzia literatura cristã e outros escritos, como hinos evangélicos. Em abril de 1891, já havia mais de cinquenta hinos traduzidos. Além desses trabalhos, fundaram o Jornal O Apologista Cristão Brasileiro, propagador das ideologias protestantes.

\section{O apologista cristão brasileiro: propagador do evangelho protestante}

O Jornal O Apologista Cristão Brasileiro foi fundado por Justus Nelson, no dia 4 de janeiro de 1890. O jornal divulgava notícias locais, nacionais e internacionais, estudos bíblicos, matérias de propaganda religiosa protestante, opiniões políticas. Tratava-se de um jornal religioso semanal, dedicado às famílias e à propaganda do "evangelho metodista". Tinha como lema: "Saibamos e pratiquemos a verdade custe o que custar" (MAUÉS, 2000).

Esse veículo de propaganda publicou várias críticas ao sistema religioso da Igreja Católica, como a devoção à Virgem Maria, acusando a referida igreja de levar seus membros à "idolatria". Devido aos artigos que publicava contra o catolicismo e os seus fiéis, considerados ofensivos, Justus Nelson foi preso e assim permaneceu durante quatro meses após tais publicações. Além de reforçar a ideologia religiosa, $O$ Apologista Cristão Brasileiro também serviu a outros fins, como atesta Salvador (1982, p. 58):

[...] publicava notícias do Brasil e do estrangeiro, atos do nosso governo, a lição resumida da Escola Bíblica Dominical, exposições doutrinárias, a taxa de câmbio, o preço da borracha, fatos religiosos e tudo mais que fosse de interesse, [...] circulava não só no Pará, mas na Amazônia, nos Estados do Norte, Pernambuco, Bahia, e mesmo em São Paulo e Rio de Janeiro tinha assinantes.

Esse jornal, além de levar as notícias aos moradores, também anunciava os dogmas metodistas, destacando o posicionamento protestante frente à Igreja Católica, sempre fazendo essa ligação entre o mundo civil e o religioso, com o intento de formar um sentimento de participação dos cidadãos na esfera pública, desfazendo a "frouxidão" da conduta moral católica e estabelecendo um novo referencial identitário para um indivíduo postular-se cristão. No jornal, Justus Nelson deixava claro quais eram os tipos de comportamento que os membros da Igreja Metodista deveriam seguir e a população em geral. Por exemplo, a proibição da mentira tornou-se primeira importância nas Regras Gerais do Metodismo brasileiro expressado pelo jornal (VILHENA, 2008). 
Essa orientação aos leitores denota o desejo de ver a população absorver novos comportamentos, rompendo em definitivo com costumes religiosos antigos, pois qualquer indivíduo que deixava suas tradições católicas e se "convertesse" ao metodismo rescindia o monopólio católico e colaborava para um novo modelo de sociedade. Consolidando assim, um novo campo religioso, onde a luta pelo poder beatificado crescia entre católicos e protestantes, influenciando principalmente na tomada das decisões políticas.

Por meio do jornal, o Reverendo Justus Nelson destaca-se como um apologista da verdade cristã, demonstrando ser profundo conhecedor da Bíblia, tinha como objetivo alertar a população local sobre outras doutrinas religiosas, utilizando conceitos bíblicos para defender os dogmas protestantes, daí o nome dado a esse jornal. O jornal posicionava-se contra os privilégios concedidos aos católicos e contra os costumes, doutrinas, dogmas, sacramentos tradicionais católicos.

Tony Vilhena (2008, p. 28) considera a produção desse jornal como o principal legado de Justus Nelson, "afinal foram vinte e um anos de uma produção que, apesar dos sacrifícios e perseguições, demarcou seu tempo [...]". O jornal idealizava um governo civil com princípios cristãos, assentado em bases religiosas, atribuindo santidade religiosa ao patriotismo e legitimidade nacionalista às crenças religiosas.

Partindo desse pressuposto, Justus Nelson acreditava que o metodismo poderia ser uma parte integrante e atuante do processo constitutivo da sociedade. O missionário estava convencido de que era um agente a serviço da implantação da civilização no país escolhido como campo missionário, por isso sua pretensão em estabelecer novos costumes condizentes com os intuitos divinos. Sua vontade era permanecer no Brasil até 1930, quando completaria o seu cinquentenário de trabalho no país, mas devido às condições financeiras precárias advindas pela crise que assolou a economia da região amazônica, não foi possível continuar sua obra missionária, retirando-se com sua família para os Estados Unidos, em 8 de novembro de 1895.

\section{Marcus Carver e a propaganda protestante em Manaus}

O protestantismo na cidade de Manaus, atual capital do Amazonas, foi propagado por meio da Igreja Metodista, em 1886, quando o Reverendo Marcus Elleworth Carver e o Reverendo Justus Nelson dirigiram-se a Manaus para iniciarem as primeiras atividades missionárias no Estado. Ao chegar à cidade de Manaus, pela primeira vez, Carver encontrou uma diversidade de 
tipos humanos, além dos nativos. Nessa época, a cidade experimentava um período de desenvolvimento econômico por causa do extrativismo gomífero (CARVALHO, 2015).

Justus Nelson, em 1886, escreveu ao Reverendo William Taylor, pedindo que enviasse pessoas para evangelizar as cidades de Santarém e Manaus. Justus, em sua carta, deixa claro que o mesmo garantiria o sustento próprio dos novos missionários. Taylor enviou três pessoas: o Reverendo Marcus Carver e o reverendo Smith com a esposa. Todavia, o casal Smith retornou a New York, e Carver, que estava destinado a iniciar a propaganda protestante em Santarém, foi enviado para Manaus (REILY, 1982).

Marcus Carver nasceu em New York (EUA), no dia 21 de março de 1863, e morreu em 24 de setembro de 1953. Formou-se em Teologia e foi enviado ao Brasil pela Sociedade Missionária da Igreja Metodista Episcopal. Carver passou curto tempo em Belém, apenas o suficiente para conhecer um pouco a região e para aprender a língua portuguesa (SALVADOR, 1982).

O Reverendo Justus Nelson descreve a chegada de Carver a Manaus e o início da propaganda metodista na cidade.

Eu o acompanhei na viagem e, na noite de 25 de dezembro de 1886, em casa do Sr. Alfredo Souza (presbiteriano), dirigi um culto, pregando o primeiro sermão protestante que consta ter-se ouvido em Manáus. Depois do meu regresso a Belém, organizamos uma Igreja Metodista Episcopal, que consistia principalmente de uma dúzia de pessoas membros de nossa igreja em Belém, porém residentes em Manaus e nos arredores (REILY, 1980, p. 14).

A partir de então, a propaganda protestante em Manaus tem como referência Marcus Carver, que aos 23 anos de idade, solteiro, foi enviado à cidade de Manaus. Os primeiros anos de propagação do evangelho metodista no Amazonas foram difíceis e improváveis. Sem condições financeiras, Marcus Carver teve dificuldades para se sustentar e manter o trabalho missionário, uma vez que toda a obra realizada era mantida por ele. Assim, como Justus Nelson, Marcus Carver manteve-se dando aulas e por meio de ofertas voluntárias de amigos e dos novos "convertidos", pois ambos faziam parte do projeto missionário de William Taylor, em que o missionário se mantinha por seus próprios esforços.

Mesmo com todas as dificuldades, as primeiras atividades de propaganda protestante coordenada pelo missionário foram realizadas na rua Apurinam (hoje, rua Leonardo Malcher), esquina com rua Bittencourt (atualmente, rua 
Jonathas Pedrosa), no bairro Praça 14, local onde se ergueu a partir de 1888 um edifício para os cultos, que serviu também para o funcionamento de uma escola primária destinada às crianças pobres, e uma casa que servia de moradia para o missionário. Em 1889, foi inaugurada a casa, e no dia 18 de setembro de 1896, sete anos depois, foi a vez de o templo ser inaugurado. O prédio possuía uma torre central na qual se encontrava um sino doado pela Missão da cidade de Peterson, Estado de New Jersey (EUA) em 1895, sendo roubado dois anos depois, foi substituído por outro, também recebido como doação (SALVADOR, 1982; CARVALHO, 2015). ${ }^{\text {' }}$

Marcus Carver, ao se estabelecer em Manaus, realizou atividades evangelísticas que consistiam em pregação da Bíblia. Isto quer dizer que publicamente proclamava sua fé por meio da leitura e proclamação dos textos bíblicos, prática comum entre os demais missionários citados. Abraçou um recurso comum em seu tempo: a palavra escrita, empregando os meios disponíveis à época para realizar suas atividades missionárias e um deles foi a publicação do Jornal $A$ Paz, por meio do qual anunciava as atividades de sua igreja, divulgava material protestante impresso colocado à venda como Bíblias, hinários e livros (CARVALHO, 2015).

\section{A Missão Betesda de Manaus}

O missionário Carver, após um tempo na cidade de Manaus, abandonou o metodismo e se aproximou da Igreja Anglicana. No dia $1^{\circ}$. de janeiro de 1888, secretamente, fundou a "Missão Bethesda" (Bethesda Mission) ${ }^{10}$ (CARVALHO, 2015).

Justus Nelson somente ficou sabendo que a missão protestante em Manaus já não tinha mais relações com a Igreja Metodista Episcopal ao comunicar ao reverendo Carver que estaria viajando de férias com sua família para a América do Norte (1889). Carver respondeu ao comunicado, informando que a obra evangelística em Manaus era um trabalho independente (REILY, 1980).

9 Conforme Carvalho (2015, p. 94), acerca dessa igreja pouco se pode descrever de sua arquitetura, mas, segundo o autor supracitado, Carver, em sua $A$ Short History (1899), afirma que se tratava de uma construção erigida próximo a um terreno acidentado, onde foram construídas uma igreja de tijolos, e também uma casa contígua que servia de habitação para o missionário.

10 Betesda ou Bethesd significa "lugar da misericórdia divina" ou "casa da misericórdia divina”. Essa missão recebeu diversos nomes, a saber, Missão Bethesda, Egreja Evangélica Amazonense, Igreja Episcopal Amazonense e Capela São Salvador (CARVALHO, 2015). 
Após seis meses de férias, a família Nelson chegou ao Pará e depois de alguns dias Justus Nelson seguiu para Manaus a fim entender-se com o reverendo Carver. Segundo Reily (1980), o missionário Carver "confirmou calmamente que há seis meses já tinha escrito, que a obra e a organização que ele chefia em Manaus, se achavam completamente desligadas da Igreja Metodista Episcopal". Dessa forma, Justus, em seu relatório de superintendente do distrito Brazil District (Pernambuco, Pará, Manaus) da Providence Annual Conference, relatou os acontecimentos que envolveram o missionário Carver, o qual foi chamado pela Conferência, a fim de se justificar por ser ainda membro da mesma.

Ao se apresentar à Conferência na América do Norte, essa instituição lhe deu a opção de escolher entre três modos de proceder, a saber:

[...] de aceitar a nomeação a pastor de uma igreja lá em Truro, ou devolver ao bispo o seu diploma de ordens sacras, retirando-se da Igreja Metodista Episcopal; ou de ver-se processado eclesiasticamente por insubordinação (REILY, 1980, p. 15).

O missionário Marcus Carver optou em renunciar às suas credenciais pastorais, retirando-se da Igreja Metodista Episcopal em definitivo, retornando a Manaus para dar continuidade às atividades da Missão Betesda.

O templo - que se fez referência na seção anterior - utilizado pela Missão Bethesda, foi destruído em um incêndio, não se sabe a causa ou a data em que ocorreu tal acontecimento. Carvalho (2015) informa que durante o ataque dois, dos cinco auxiliares de Marcus Carver, foram agredidos e em pouco tempo morreram por causa dos ferimentos. Um novo templo no Bairro Vila Municipal foi construído e recebeu o nome de Capela Salvador.

Em sua missão, Carver prestava assistência espiritual e social aos estrangeiros que viviam em Manaus. Carvalho (2015) sustenta que essa pode ter sido a motivação de ter se desvinculado da Igreja Metodista. Partindo dessa hipótese, conclui-se que os estrangeiros pareciam potenciais para a evangelização e conversão, e daí torná-los membros da nova igreja. Além dos estrangeiros, a missão dava assistência religiosa aos barbadianos - grupos de negros imigrantes vindos das Ilhas Britânicas no Caribe - que residiam em Manaus, no Bairro Praça 14, para os quais Carver dedicou especial atenção (CARVALHO, 2015). 
Salvador (1982) afirma que a Missão Betesda, no dia 18 de setembro de 1899, transformou-se Igreja Evangélica Amazonense, com estatuto próprio e ritual semelhante ao da Igreja Metodista. Isto quer dizer que os rituais, os sacramentos, dessa igreja eram os mesmos da Igreja Metodista Episcopal. Carver, ao desligar-se da Igreja Metodista Episcopal dos Estados Unidos, foi totalmente abandonado pela missão metodista, realizando seu trabalho sozinho, sem apoio financeiro, religioso e administrativo. Realizou um trabalho independente, dedicando sua vida ao Amazonas, estendendo suas atividades de evangelização também aos povos indígenas.

De acordo com Carvalho (2015), a Egreja Evangélica Amazonense instalou-se definitivamente no templo da Av. Major Gabriel. O local em que ficava essa igreja hoje está ocupado por um centro comercial, tendo ao seu lado um templo da Igreja Evangélica Holiness, e bem próxima, a residência da família do Rev. Juvêncio Paulo de Melo.

O evangelista Juvêncio Paulo de Mello (funcionário da Manaós Harbour Limited, empresa inglesa que administrava o Porto de Manaus) com sua família (esposa e duas filhas) foram grandes colaboradores de Carver na divulgação da doutrina protestante no Amazonas. Por meio do trabalho desses pastores, a Missão Betesda desenvolveu intensa atividade missionária em toda a cidade de Manaus, crescendo rapidamente (BARROS, 2010). Além disso, a Missão Betesda fundou o Jornal A Paz. "É datado de 21 de março de 1898. Redator: Rev. Marcus Elleworth Carver; secretário: Juvêncio de Mello. Publicação mensal" (OLIVEIRA, 2010, p. 2).

Esse jornal circulou de 1898 a 1900, em Manaus. Assim, vale transcrever do número 1 do ano I de A PAZ, o seguinte, ${ }^{11}$ de acordo com a transcrição de Oliveira (2010, p. 1):

Despido das galas mundanas surge hoje nas plagas Amazonenses, êste humilde periódico Evangélico denominado A Paz, como órgão Official da Missão Bethesda de Manáos. Vencendo muitas difficuldades, e ajudado por Deus, a Missão conseguiu montar uma pequena typographia onde será impresso A PAZ que terá por fim único e exclusivo tratar dos actos da Missão, e especialmente à propaganda das virtudes do Evangelho de Jesus Christo, neste vasto campo da Amazônia. A sua direção e redacção está confiada aos propagadores do Evangelho, Revd. Marcus E. Carver e ao Evangelista Juvencio de Mello, de quem a Missão espera as suas valiosas coadjuvações, no sentido de, com

11 A pesquisadora Betty Oliveira foi fiel à transcrição dos textos originais do referido jornal e isso não compromete o entendimento da leitura. 
os seus concursos intellectuais fazerem chegar ao conhecimento desta população a verdadeira doutrina do Divino Mestre Christo Jesus. Muitas serão as difficuldades que hão de aparecer, porem, confiamos nos nossos irmãos na fé, que nos auxiliem com as suas assignaturas, e de Deus esperamos a benção para esta tão brilhante obra. Desejamos também dizer aos leitores que A Paz não vem plantar discórdias nos corações dos homens, porém tem por seu lemma as suplimes palavras que Christo disse aos seus discípulos: - A PAZ SEJA CONVOSCO.

O objetivo desse jornal consistia em contribuir para a divulgação do evangelho protestante, dos cultos, da Escola Dominical da Missão Betesda, na orientação de pessoas, no que tange à ética, valores, costumes, moral. O jornal era um veículo que contribuía no cumprimento da ordenação: "Ide por todo mundo e pregai o Evangelho a toda criatura" (Marcos 16.15).

Carver sentia-se na responsabilidade de propagar esse evangelho aos amazonenses, trabalho realizado por meio da distribuição de Bíblias, literatura cristã, cultos ao ar livre e pelo Jornal A Paz. Oliveira (2010, p. 2) ressalta que A Paz é o primeiro jornal evangélico de Manaus, quiçá do Amazonas que circulou pelos municípios do Estado.

Barros (2010) destaca que a Igreja Evangélica Amazonense viveu e cresceu como uma igreja independente, apesar de seus insistentes apelos para se filiar à igreja episcopal. O fundador da Igreja Evangélica Amazonense solicitou muitas vezes aos clérigos da Igreja Episcopal que assumissem as atividades e recebessem como doação as propriedades da referida igreja. Entretanto, não se sabe ao certo quais foram os motivos que levaram Carver a solicitar a integração da Igreja Evangélica Amazonense à Igreja Episcopal.

Carver retornou aos Estados Unidos, em 1908, assumindo a igreja o evangelista Juvêncio Mello. O novo pastor também por muitas vezes escreveu cartas, solicitando a inclusão de sua Igreja à convenção episcopal, colocando-se à disposição para obedecer sem reservas e discrepâncias todos os seus dogmas e costumes. Conforme Barros (2010), a declaração dos líderes episcopais em não aceitar os membros da Igreja Evangélica Amazonense era por causa da distância geográfica, a falta de recursos financeiros e de missionários que viessem para o Amazonas.

O pastor Juvêncio Mello esteve à frente da Igreja Evangélica Amazonense até a sua morte, em 1934. Durante esse período, dirigiu o jornal O Monitor, o qual era editado por Francisco Farias de Carvalho. Esse jornal tinha por lema for Christ and the Church (Por Cristo e pela Igreja) e substituiu o jornal A Paz: 
Diante da ausência de um pastor, após a morte de Juvêncio de Mello, em seu lugar ficou o professor e dentista Clemente Thomas, convencionado ao cargo de pastor pelos próprios membros da igreja. Sendo que, em janeiro de 1944, as atividades da igreja foram encerradas.

No final da década de 1970, o bispo Edmund Knox Sherril aproveitou as viagens que fazia ao exterior para visitar Manaus e realizou alguns cultos na residência da Dona Josephina de Mello, filha do pastor Juvêncio, que no começo dos anos 1990 doou as propriedades que ainda lhe restavam para a Igreja Episcopal Anglicana do Brasil por meio de testamento.

\section{Considerações finais}

A teologia protestante, que, de forma bastante lenta, fixou-se no território amazônico, herdeira da filosofia ligada à Reforma protestante, trouxe novas perspectivas religiosas para os moradores locais. A propaganda protestante foi a grande novidade do século XIX para a Amazônia, época em que no Brasil as ideologias modernizadoras imperavam.

Nesse tempo, a entrada de imigrantes da Europa e dos Estados Unidos da América era frequente. Os norte-americanos adentraram o país com o objetivo de propagar a sua fé por meio da educação, da conversão e do proselitismo. Os estadunidenses embrenharam-se também pelo território amazônico, tentando propagar por meio da distribuição de Bíblias e literatura cristã suas crenças. Trata-se de um grupo de missionários que além do desejo de tornar os moradores locais conhecedores dos textos bíblicos também almejavam que a Amazônia progredisse economicamente, socialmente, politicamente e culturalmente a partir dos valores norte-americanos, fundamentados na ideologia do destino manifesto.

Os protestantes estadunidenses escolheram a Amazônia por causa da falta de propaganda protestante, acreditando que por meio do protestantismo a região alcançaria o progresso. Desse modo, a região aparece no imaginário dos missionários protestantes promissora ao desenvolvimento econômico.

O protestantismo destaca-se em um cenário econômico e político, onde os missionários defendiam um governo que fosse soberano sobre a Amazônia, que tornasse a região dentro dos paramentos do "sonho americano". Desse modo, o protestantismo é a influência mais recente que a Amazônia passa a viver. Trata-se de um protestantismo da conversão, da mudança de vida, do proselitismo, da negação da própria cultura. Assim, o protestantismo reproduziu novas práticas messiânicas de evangelização e de colonização, gerando assim, uma nova dinâmica social e religiosa. 
A vida religiosa amazonense é, majoritariamente, um sistema de crenças e ritos influenciados pelo catolicismo e protestantismo. Esses dois ramos do cristianismo tornaram-se, portanto, definidores das matrizes éticas de condutas e valores que permeiam as esferas do sagrado e do profano. Por meio do seu ethos, "organizaram" a vida social amazônica, ao mesmo tempo estabelecendo os deveres e os prazeres.

Hoje, as igrejas evangélicas podem ser encontradas em todos os lugares do Estado, estruturadas em organizações compostas de liturgias, datas festivas e formação eclesiástica. As mesmas são fruto do trabalho de igrejas e organizações missionárias norte-americanas e europeias. Estas influenciaram na formação da vida religiosa das populações amazônicas no que tange à sua "identidade cristã", a qual se exprime em estilos de vida, conduta, costumes, valores, princípios.

\section{Referências}

ALENCAR, Gedeon. Protestantismo Tupiniquim: Hipóteses da (não) contribuição evangélica à cultura brasileira. São Paulo: Arte Editorial, 2005.

BARROS, Saulo Maurício de. História do Anglicanismo na região amazônica. Centro de Estudos Anglicanos. Disponível em: <www.centroestudosanglicanos.com.br/.../hist_anglicanismo_amazonia_saulo.pdf>. Acesso em: 10. out. 2010.

CARVAlHO, Sandro Amorim de Carvalho. O Povo do Livro: uma historia da inserção do Protestantismo em Manaus (1888-1944). Dissertação de Mestrado (Mestrado em História). Manaus: Universidade Federal do Amazonas, 2015.

CERETTA, Pe. Celestino. História da Igreja na Amazônia Central. Manaus: Biblos/Valer, 2008. FILHO, Sergio Willian de Castro Oliveira. Temperança a bordo: o Reverendo Metodista Daniel Kidder e sua pregação contra o consumo do álcool durante suas viagens pelo Império do Brasil. Revista Navigator, n. 17, mai. 2013.

KIDDER, Daniel Parish. Reminiscências de viagens e permanência no Brasil (Províncias do Norte). Tradução de Moacir N. Vasconcelos. São Paulo, SP: Martins, Editora da Universidade de São Paulo, 1972.

LONG, Eula Kennedy. Do meu baú Metodista. São Paulo: Junta Geral de Educação Cristã Igreja Metodista do Brasil, 1968.

MATOS, Alderi de Souza. Historia do Movimento reformado: A Igreja reformada na Holanda. Instituto Presbiteriano Mackenzie, 2011. Disponível em: http://www.mackenzie. br/7010.html. Acesso em 12 jul. 2015.

Breve História do Protestantismo no Brasil. Revista de Teologia da Faculdade FAIFA, v. 3, n. 1, 2011.

MAUÉS, Raymundo Heraldo. Cristianismos Amazônicos e Liberdade religiosa: Uma abordagem histórico-antropologica. Trabalho apresentado na Oficina sobre Direitos Huma- 
nos, Liberdade Religiosa e Territorialidade, da Associação Brasileira de Antropologia (ABA). Revista Antropolítica. São Luis: n. 9, p. 77-100, 2000.

MENDONÇA, Antonio Gouvêa; FILHO, Prócoro Velasques. Introdução ao Protestantismo no Brasil, 2. ed. São Paulo: Edições Loyola, 2002.

MENDONÇA, Antônio Gouvêa. O Celeste Porvir: A inserção do Protestantismo no Brasil, 3. ed. São Paulo: Editora da Universidade de São Paulo, 2008.

OLIVEIRA, Betty Antunes de. Metodistas no Brasil antes de 1900. Disponível em: <www.pibrj.org.br/historia>. Acesso 15 out. 2010.

O primeiro Jornal do Amazonas [Publicado no "O Jornal Batista", Rio de Janeiro, 10 setembro de 1967, p. 10.] Disponível em: <www.pibrj.org.br/historia/arquivos/EvangAM. pdf>. Acesso em: 15 out. 2010.

PANTOJA, Vanda. Debates do NER. Porto Alegre, ano 13, n. 21 p. 95-122, jan./jun. 2012.

REILY, Duncan Alexander. Metodismo na Amazônia: a obra pioneira de Justus Nelson (1880-1925). São Bernardo do Campo: Faculdade de Teologia da Igreja Metodista e Instituto Metodista de Nível Superior, 1982.

RIBEIRO, Lidice Meyer Pinto. Protestantismo Rural: um Protestantismo genuinamente brasileiro. In: FERREIRA, João Cesário Leonel (Org.). Novas Perspectivas sobre o Protestantismo Brasileiro. São Paulo: Fonte Editorial/Paulinas, 2009, p. 189-229.

ROCHA, Isnard. Pioneiros e Bandeirantes do Metodismo no Brasil. São Bernardo do Campo: Imprensa Metodista, 1967.

ROSI, Bruno Gonçalves. Exploradores, Missionários, Cientistas e a abertura do Amazonas. Revista Conjuntura Austral, v. 2, n. 7, ago./set. 2011, p. 67-88.

SALVADOR, José Gonçalves. O Metodismo no Norte e Nordeste do Brasil. In: História do Metodismo no Brasil: dos Primórdios á Proclamação da República (1835-1890), v. I. Rio de Janeiro: Centro Metodista Vila Isabel, 1982.

SILVA, Marilene Corrêa da. O Paiz do Amazonas. Manaus: Editora da Universidade do Amazonas, 1996.

TUNES, Suzel Magalhães. Ecumenismo no jornal Expositor Cristão: a cobertura do ingresso da Igreja Metodista no Conselho Nacional de Igrejas, Cristãs, CONIC. Revista Caminhando, v. 14 , n. 1 , p. 125,136 , jan./jun. 2009.

VIEIRA, David Gueiros. O Protestantismo, a Maçonaria e a Questão Religiosa no Brasil, 2. ed. Brasília: Editora UnB, 1980.

VILHENA, Tony Welliton da Silva. O pensamento político do Jornal O Apologista Christão Brazileiro na transição juridopolítica do Estado Nacional (1890-1891). Trabalho de Conclusão de Curso em Ciências Sociais. Belém: Universidade Federal do Pará/UFPA, 2008.

Submetido em: 3-12-2016

Aceito em: 6-8-2017 